\title{
SISTEM PAKAR BAWANG DAYAK SEBAGAI OBAT ALTERNATIF
}

\author{
Joan Angelina Widians ${ }^{1}$, Novianti Puspitasari², Tri Basuki Kurniawan ${ }^{3}$ \\ ${ }^{1,2}$ Program Studi Teknik Informatika, Universitas Mulawarman \\ ${ }^{3}$ Program Studi Sistem Informasi, Universitas Bina Darma \\ email :1,2,angel.unmul@gmail.com, ${ }^{3}$ tribasukikurniawan@binadarma.ac.id
}

\begin{abstract}
The medicinal plants that have been developed especially in East Kalimantan is the dayak onion (Eleutherine palmifolia (L.) Merr). The Dayak onion herb has long been used by the Dayak tribe as an alternative medicine. Information of the possibility of people affected by the disease and how to process Dayak onion ingredients, an expert system needs to build that is able to diagnose the disease and how to process Dayak onion ingredients. The result of this research is an expert system with Certainty Factor that helps the general public in early diagnosis of ten diseases and provides alternative treatment solutions and ways of Dayak onion as an alternative medicine.
\end{abstract}

Keywords: Expert System, Dayak Onion, Certainty Factor

\begin{abstract}
Abstrak
Tanaman obat yang sudah dikembangkan khususnya di daerah Kalimantan Timur yaitu bawang dayak (Eleutherine palmifolia (L.) Merr). Ramuan bawang dayak sudah lama dimanfaatkan oleh suku Dayak sebagai obat alternatif berbagai macam penyakit. Informasi mengenai kemungkinan masyarakat terkena penyakit dan cara pengolahan ramuan bawang Dayak diperlukan sistem pakar yang mampu mendiagnosa penyakit serta cara pengolahan ramuan bawang Dayak yang tepat. Hasil dari penelitian ini adalah sebuah sistem pakar bawang dayak dengan metode Certainty Factor yang membantu masyarakat umum dalam diagnosa dini sepuluh penyakit, dan memberikan solusi pengobatan alternative serta cara pengolahan ramuan bawang dayak sebagai obat alternatif.
\end{abstract}

Kata kunci: Sistem Pakar, Bawang Dayak, Certainty Factor 


\section{PENDAHULUAN}

Kalimantan menyimpan potensi keanekaragaman hayati yang tinggi, termasuk tumbuhan hutan berkhasiat obat (THBO) yang telah lama dikenal dan dimanfaatkan oleh berbagai etnis di Kalimantan untuk mengobati berbagai macam penyakit. Perkembangan pemakaian obat tradisional semakin berkembang pesat,hal ini didukung oleh kecenderungan manusia melakukan pengobatan secara alam atau kembali ke alam. Salah satu tanaman obat yang sudah dikembangkan khususnya di Kalimantan Timur adalah tanaman bawang dayak (Eleutherine palmifolia (L.) Merr). Tanaman ini mempunyai bentuk dan jenis yang beragam serta sudah secara turun temurun digunakan masyarakat suku Dayak sebagai obat berbagai jenis penyakit. Potensi bawang dayak sebagai tanaman obat multi fungsi sangat besar sehingga perlu ditingkatkan informasi mengenai bawang dayak.

Ramuan bawang dayak sudah lama dimanfaatkan masyarakat Dayak sebagai obat alternative berbagai macam penyakit, namun untuk informasi kepada masyarakat mengenai cara pengolahan ramuan bawang Dayak sangatlah kurang, maka perlu dikembangkan teknologi informasi yang membantu masyarakat mendapatkan informasi pengetahuan tumbuhan berkhasiat obat yaitu bawang dayak. Penelitian ini membuat suatu sistem pakar berbasis website dalam mendiagnosa dini berbagai jenis penyakit, dan cara pengolahan bawang dayak, sehingga dapat membantu masyarakat umum mendapat informasi penyakit yang dideritanya dan cara pengolahan ramuan bawang dayak sebagai obat alternatif.

\subsection{Sistem Pakar}

Perkembangan teknologi informasi sangat cepat dan mengarah pada kecanggihan, yang bertujuan membantu aktivitas kerja manusia agar menjadi mudah dan cepat (Brezensky \& Kurniawan, 2019). Sistem pakar merupakan sistem yang mengadopsi pengetahuan seorang ahli ke komputer agar komputer tersebut dapat menyelesaikan masalah seperti yang biasa dilakukan para ahli / pakar (Joan Angelina Widians \& Rizkyani, 2020), (Joan Angelina Widians \& Wati, 2017). Sistem pakar diharapkan dapat menyelesaikan suatu permasalahan tertentu dengan meniru kerja dari para ahli. Sistem pakar mencoba mencari solusi yang tepat sebagaimana yang dilakukan seorang pakar dan dapat memberikan penjelasan terhadap langkah yang diambil serta memberikan alasan atas saran atau kesimpulan yang diperoleh (J.A. Widians, Puspitasari, \& Sari, 2019), (J.A.Widians \& Budiman, 2020), (J.A.Widians \& Hidayati, 2016).

\subsection{Bawang dayak}

Salah satu tumbuhan obat yang sudah dikembangkan khususnya di daerah Kalimantan Timur adalah tanaman Bawang Dayak (Eleutherine palmifolia (L.) Merr), dengan nama daerah bawang berlian, bawang tiwai (Arwati et al., 2018), (Budiman et al., 2018), (J.A.Widians, Pakpahan, Budiman, et al., 2019). Bawang dayak memiliki nama asing changp'ciang (Cina), genggibre (Spanyol), ingafaera (Swedia), imbir (Rusia), halia (Malaysia), nyabil (Arab), dan ginger (Inggris). Sama seperti bawang pada umumnya, Bawang Dayak juga dikembangkan dari umbinya (Harlita et al., 2018). Kandungan zat kimia Bawang Dayak adalah alkaloid, flavonoid, glikosida, saponin, dan tannin yang mampu menyembuhkan berbagai macam penyakit (Arwati et al., 2018),(J.A.Widians et al., 2018).

Penemuan khasiat Bawang Dayak sebagai pengobatan herbal ini sebetulnya berasal dari kebiasaan warga Kalimantan pedalaman yang menggunakan Bawang Dayak ini sebagai obat berbagai macam penyakit yang kemudian dilakukan penelitian oleh banyak kalangan hingga ditemukan banyak sekali manfaat Bawang Dayak sebagai pengobatan alternatif. Namun, informasi mengenai hal ini belum banyak diketahui oleh masyarakat. Hal ini dikarenakan tumbuhan ini hanya ditemukan pada daerah tertentu saja (Dengen et al., 2018), (Budiman et al., 2018), (Johan et al., 2017). 
Dalam penelitian ini terdapat 10 (sepuluh) penyakit yang dapat didiagnosa dan kandungan senyawa dari bawang dayak untuk pengobatan alternative sebagai berikut.

\section{a. Ambeien}

Ambeien adalah bengkak pada pembuluh darah vena di bagian rektum dan menimbulkan rasa sakit. Gangguan ini sering kali menyebabkan berak berdarah pada penderitanya. Berak berdarah biasa terjadi akibat adanya tekanan pada pembuluh di bagian rectum yang membengkak. Umbi bawang dayak mentah bersifat menyejukkan, menghentikan pendarahan, dan menyembuhkan peradangan poros usus. Selain itu, kandungan tanin di dalam bawang dayak dapat menghentikan adanya pendarahan (Lesmana \& Parman, 2019).

\section{b. Nefrolithiasis}

Nefrolithiasis atau batu ginjal merupakan suatu kedaan jika terdapat satu atau lebih batu di dalam pelvis atau calyces ginjal atau di dalam saluran ureter. Pembentukan batu ginjal dapat terjadi di seluruh bagian saluran kencing. Namun biasanya terbentuk pada dua bagian terbanyak dari ginjal, yaitu di bagian renal pelvis dan calix renalis. Gejala khas penyakit batu ginjal adalah pinggang terasa tidak nyaman apalagi saat ingin buang air kecil terasa nyeri. Gejala tersebut biasa dipicu karena kurangnya konsumsi air putih dalam jangka waktu sehari dan disertai pola hidup yang tidak baik, seperti menahan kencing sehingga mengakibatkan adanya batu dalam ginjal. Kandungan flavonoid dalam bawang dayak mampu mengatasi radang batu ginjal (Arwati et al., 2018).

\section{c. Diabetes Mellitus}

Diabetes mellitus disebabkan ketidakcukupan hormon insulin yang dihasilkan oleh pancreas untuk menetralisir gula darah di dalam tubuh. Hormon insulin berguna untuk memproses zat gula atau glukosa yang berasal dari makanan dan minuman. Penderita diabetes umumnya mengalami kerusakan atau penurunan kemampuan kerja organ pankreas. Akibatnya tubuh tidak mampu menghasilkan hormon insulin dalam jumlah yang cukup. Kandungan aktif senyawa alkaloid, glikosida, dan flavonoid dalam bawang dayak berperan sebagai obat anti-diabetes dengan cara mengontrol kadar gula darah serta mengoptimalkan kerja organ pancreas (Hasni et al., 2019).

\section{d. Hipertensi}

Hipertensi atau tekanan darah tinggi merupakan suatu keadaan ketika seseorang mengalami peningkatan tekanan darah di atas batas normal. Peningkatan tekanan darah ditunjukan dari nilai sistolik dan dan diastolik pada pemeriksaan tekanan darah menggunakan alat pengukur sphygmomanometer atau pengukur tekanan darah digital. Nilai normal tekanan darah seseorang secara umum adalah 120/80 $\mathrm{mmHg}$. Umbi bawang dayak mengandung flavonoid untuk mengurangi kadar kolesterol, dan melancarkan peredaran darah serta mencegah terjadinya penyumbatan pada pembuluh darah sehingga darah mengalir normal (Setyawan, 2019).

\section{e. Hepatitis}

Hepatitis atau penyakit hati merupakan peradangan organ hati karena berbagai sebab. Hepatitis biasanya terjadi karena virus hepatitis. Ada lima jenis virus penyebab hepatitis, yakni virus hepatitis A, B, C, D, dan E. hepatitis bisa juga disebabkan infeksi virus lainnya, seperti mononucleosis infeksiosa, demam kuning, dan infeksi sitomegalovirus. Sementara itu, penyebab hepatitis non-virus yang utama adalah alcohol dan obat-obatan. Penyakit hepatitis bersifat akut jika berlangsung kurang dari enam bulan dan disebut kronis jika berlangsung lebih dari enam bulan Kandungan dalam bawang dayak dapat menyembuhkan hepatitis (J.A. Widians, Puspitasari, \& Febriansyah, 2019).

\section{f. Tuberkulosis}

Tuberkulosis merupakan penyakit sistemik yang disebabkan oleh infeksi bakteri mycobacterium tuberculosis dan dapat bermanifestasi pada hampir semua organ tubuh. Lokasi primer serangan bakteri mycobacterium tuberculosis adalah paru-paru, tetapi dapat juga menyerang organ tubuh lainnya. Polusi udara yang terjadi saat ini sudah semakin 
mengkhawatirkan dan menjadi faktor penyumbang utama penyebab terjadinya tuberculosis. Kandungan dalam umbi bawang dayak dapat menyembuhkan tuberkulosis (Harlita et al., 2018).

\section{g. Bronkitis}

Bronkitis merupakan suatu peradangan pada bronkus (saluran udara pada paru-paru). Penyakit ini biasanya bersifat ringan, tetap tidak akan sembuh sempurna pada akhirnya. Bronchitis bisa juga bersifat serius pada penderita hepatitis yang memiliki penyakit menahun, seperti penyakit jantung atau penyakit paru-paru serta berusia lanjut. Bronkitis infeksiosa disebabkan oleh virus, bakteri, dan organisme yang menyerupai bakteri ( mycoplasma pneumonia dan chlamydia). Flavonoid yang terkandung dalam bawang dayak berfungsi sebagai obat antibakteri sehingga kuman yang ada pada saluran pernapasan dapat teratasi (Harlita et al., 2018).

\section{h. Sinusitis}

Sinusitis adalah peradangan pada sinus akibat alergi, infeksi virus, bakteri, atau jamur. Sinusitis bisa terjadi pada salah satu dari keempat sinus yang ada (maksilaris, etmoidalis, frontalis, atau sfenoidalis). Sinusitis bisa bersifat akut (berlangsung selama 3 minggu atau kurang) maupun kronis yang berlangsung selama 3-8 minggu, tetapi dapat berlanjut hingga berbulan-bulan bahkan bertahun-tahun. Kandungan senyawa flavonoid dan tannin dalam bawang dayak mampu bekerja meredakan sinusitis (J.A. Widians, Puspitasari, \& Febriansyah, 2019).

\section{i. Asam Urat}

Asam urat merupakan penyakit pada sendi yang disebabkan pembentukan atau pengendapan monosodium urat di sendi atau jaringan tertentu. Gejala asam urat biasanya berupa rasa nyeri di bagian sendi tangan atau kaki. Kandungan senyawa aktif flavonoid pada bawang dayak berperan dalam mengahambat pembentukan Kristal oksalat pada persendian (J.A. Widians, Puspitasari, \& Febriansyah, 2019), (Bahtiar \& Dewi, 2019).

\section{j. Rematik}

Rematik merupakan suatu cairan yang dianggap jahat, mengalir dari otak menuju ke sendi dan bagian tubuh lain sehingga menimbulkan rasa nyeri. Rematik juga diartikan setiap kondisi yang disertai rasa nyeri dan kaku pada sistem musculoskeletal (sistem rangka dan otot). Penyakit rematik ada empat macam, yaitu osteoarthritis, arthritis rheumatoid, polimialgia rheumatoid, dan arthritis gout. Kandungan zat aktif seperti flavonoid dan tannin dalam bawang dayak berfungsi sebagai pereda rematik (Bahtiar \& Dewi, 2019).

\subsection{Certainty Factor}

Faktor Kepastian (Certainty Factor) menyatakan kepercayaan dalam sebuah kejadian (fakta atau hipotesis) berdasarkan bukti atau penilaian pakar (Gunawan \& Wardoyo, 2018). Cara dalam memperoleh tingkat keyakinan (CF) dari sebuah rule, yaitu melalui mewawancarai seorang pakar. Nilai CF (rule) diperoleh dari interpretasi "term" dari pakar, yang diubah menjadi nilai CF tertentu sesuai tabel 1 (J.A. Widians et al., 2018).

Tabel 1. Nilai CF dan Interpretasi

\begin{tabular}{|l|c|}
\hline \multicolumn{1}{|c|}{ Uncertain Term } & CF \\
\hline Definitely not (pasti tidak) & -1.0 \\
\hline Almost certainly not (hampir pasti tidak) & -0.8 \\
\hline Probably not (kemungkinan besar tidak) & -0.6 \\
\hline Maybe not (mungkin tidak) & -0.4 \\
\hline Unknown (tidak tahu) & -02 to 0.2 \\
\hline Maybe (mungkin) & 0.4 \\
\hline Probably (kemungkinan besar) & 0.6 \\
\hline Almost certainly (hampir pasti) & 0.8 \\
\hline Definitely (pasti) & 1.0 \\
\hline
\end{tabular}


Certainty Factor menggunakan suatu nilai yang mengasumsikan derajat keyakinan seorang pakar terhadap suatu data. Certainty Factor digunakan juga dalam menentukan nilai keyakinan atas fakta awal yang diberikan pengguna (J.A. Widians et al., 2018). Dalam Certainty Factor, data-data kualitatif direpresentasikan sebagai derajat keyakinan dan ketidakyakinan yang tercantum pada persamaan sebagai berikut:

IF E THEN H (CF rule)

$\mathrm{CF}(\mathrm{H}, \mathrm{E})=\mathrm{CF}(\mathrm{E}) \times(\mathrm{CF}$ rule $)$

Secara praktik, nilai CF rule ditentukan oleh pakar, sedangkan nilai $\mathrm{CF}(\mathrm{E})$ ditentukan oleh pengguna saat berkonsultasi dengan sistem pakar.

CF paralel merupakan CF akhir dari sebuah calon konklusi. CF paralel diperlukan jika suatu konklusi diperoleh dari beberapa aturan sekaligus. CF Akhir dari suatu aturan dengan aturan yang lain digabungkan untuk mendapatkan nilai $\mathrm{CF}$ akhir bagi calon konklusi tersebut. $\mathrm{CF}$ paralel direpresentasikan dalam persamaan (2) berikut ini :

$\mathrm{CF}(\mathrm{H} \mid \mathrm{E} 1: \mathrm{E} 2)=\mathrm{CF}(\mathrm{MB}(\mathrm{H} \mid \mathrm{E} 1))+\mathrm{CF}(\mathrm{MB}(\mathrm{H} \mid \mathrm{E} 2))=$

$(1(\mathrm{MB}(\mathrm{H} \mid \mathrm{E} 1)))$.

Dimana :

$\mathrm{CF}(\mathrm{H} \mid \mathrm{E} 1 ; \mathrm{E} 2)=$ Parallel Certanty Factor dalam

hipotesa $H$ yang dipengaruhi oleh gejala $E 1$ dan $E 2$

$\mathrm{CF}(\mathrm{MB}(\mathrm{H} \mid \mathrm{E} 2))=$ Measure of Belief merupakan ukuran kenaikan dari kepercayaan hipotesa

$H$ dipengaruhi oleh gejala $E 1$ (diantara 0 dan 1$)$

$(1-(\mathrm{MB}(\mathrm{H} \mid \mathrm{E} 1)))=$ Measure of Belief merupakan

ukuran kenaikan dari kepercayaan hipotesa $H$ dipengaruhi oleh gejala $E 2$

Atau persamaan (2) dapat ditulis sebagai. [13]

CFcombine $(\mathrm{CF} 1, \mathrm{CF} 2)=\mathrm{CF} 1+\mathrm{CF} 2(1-\mathrm{CF} 1)$

\section{HASIL DAN PEMBAHASAN}

\subsection{Deskripsi Sistem}

Pada penelitian ini dibangun suatu sistem pakar yang menggunakan keahlian pakar dalam bidang kesehatan dengan menggunakan metode Certainty Factor dalam mendiagnosa sebuah penyakit sehingga validasi sistem dapat dipertanggung jawabkan. Metode Certainty Factor merupakan metode yang mudah dibandingkan metode sistem pakar yang lainnya karena selain perhitungannya yang lebih mudah, metode Certainty Factor juga memiliki nilai intepretasi ketidakpastian yang menunjukkan besarnya kepercayaan seorang pakar terhadap suatu masalah. Sistem pakar ini dapat mendiagnosa berbagai jenis penyakit yang diderita masyarakat dan cara pengolahan bawang dayak untuk dijadikan obat yang nantinya dapat membantu masyarakat yang ingin mengetahui informasi penyakit yang diderita dan cara pengolahan bawang dayak untuk dijadikan obat alternatif.

Sistem pakar diagnosa penyakit menggunakan bawang dayak sebagai obat alternatif ini menggunakan metode inferensi forward chaining (penalaran maju) dan teori faktor kepastian (certainty factor), dalam metode ini user akan memilih gejala sesuai dengan yang dialaminya, kemudian sistem akan mengecek satu demi satu gejala yang dipilih user apakah rule di dalam database ada yang sesuai dengan inputan user. Dalam pemenuhan basis pengetahuan 
(knowledgebase) dilakukan dengan pengumpulan data dan informasi terkait penyakit Ambeien, Nefrolithiasis, Diabetes Melitus, Hipertensi, Hepatitis, Tuberkulosis, Bronkitis, Sinusitis, Asam urat, dan Rematik, dengan studi pustaka dan konsultasi dengan pakar. Adapun konsep mesin inferensi (inference engine) dilakukan dengan penggunaan aturan produksi (production rule) yaitu (if..then), dengan mekanisme perunutan forward chaining serta penilaian bobot menggunakan nilai CF beserta intrepretasinya. Konsep user interace dan dialog dikembangkan dengan pembuatan antarmuka yang userfriendly bagi kemudahan dalam pengisian data dan fakta. Sistem akan memberikan output berupa diagnosis penyakit berupa nama penyakit, besarnya nilai persentase $\mathrm{CF}$ hasil diagnosis sistem, serta penjelasan solusi penanganan dan pengobatan penyakit dengan ramuan Bawang Dayak.

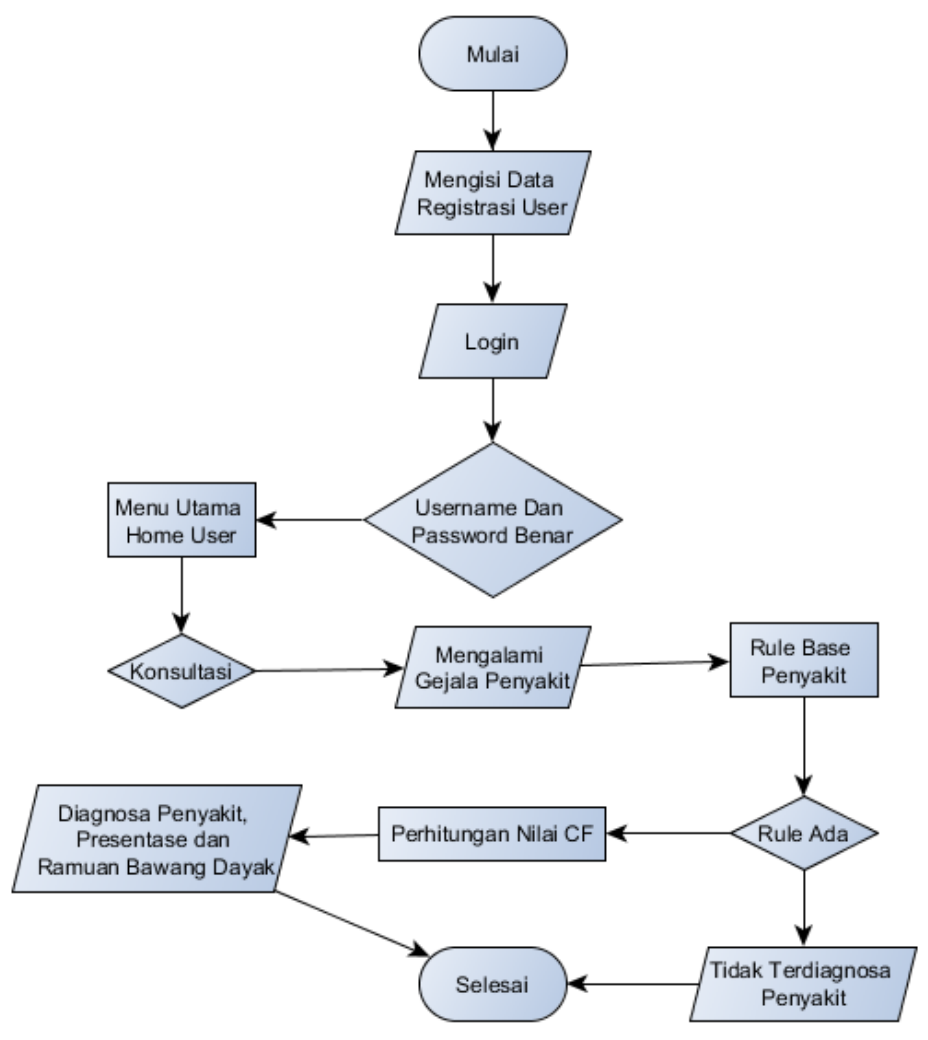

Gambar 1.Alur Rancangan Diagnosa Penyakit

Alur rancangan sistem pakar ini pada gambar 1 yaitu:

a. User yang belum memiliki akun dapat mengisi data registrasi user terlebih dahulu sebagai syarat user untuk dapat berkonsultasi pada sistem pakar ini.

b. User dapat melakukan login setelah melakukan registrasi pembuatan akun user.

c. Apabila password dan username yang diinputkan user benar maka user akan masuk ke dalam halaman home user dan akan dihadapkan menu utama pada home tersebut. Apabila username dan password salah maka user tidak dapat masuk ke dalam akun dan akan kembali melakukan login.

d. Kemudian menginput gejala Jika user mengalami gejala dari suatu penyakit maka user dapat didiagnosa sebagai suspek penyakit melalui beberapa tahapan proses yaitu inputan gejala yang telah diinputkan akan dieksekusi sesuai rule base Suspek penyakit yang ada.

e. Perhitungan nilai CF untuk rule base dan setiap gejalanya akan dilakukan setelah inputan gejala dieksekusi sesuai dengan rule base. 
f. Sistem akan memberikan keluaran berupa diagnosis suspek penyakit, persentase diagnosis, dan cara pengolahan bawang dayak setelah perhitungan nilai CF dilakukan.

\subsection{Implementasi Sistem}

a. Halaman Utama

Halaman utama yang pertama kali tampil ketika pengguna mengakses sistem dapat dilihat pada gambar 2. Pengguna website sistem pakar ini adalah user dan admin. Halaman utama memiliki menu yang terletak di bagian atas halaman.

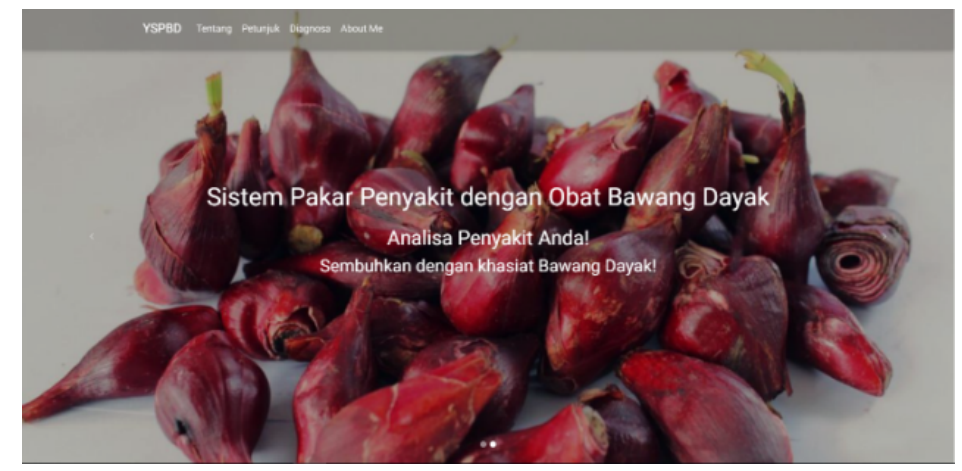

Gambar 2. Halaman Utama Sistem

\section{b. Halaman Diagnosa}

Halaman Diagnosa merupakan halaman yang dapat digunakan user untuk melakukan diagnosa tentang gejala yang dirasakan oleh user. Halaman diagnosa berisi daftar gejala beserta pertanyaan apakah user, tidak tau, agak yakin, cukup yakin, yakin atau sangat yakin mengalami gejala tersebut. Inputan gejala user akan menjadi masukan sistem pakar untuk diproses, kemudian sistem akan mendiagnosa persentasi kemungkinan user mengalami penyakit menggunakan metode Certainty Factor. User memilih gejala penyakit yang dialami. Tampilan Form gejala dapat dilihat pada gambar 3.

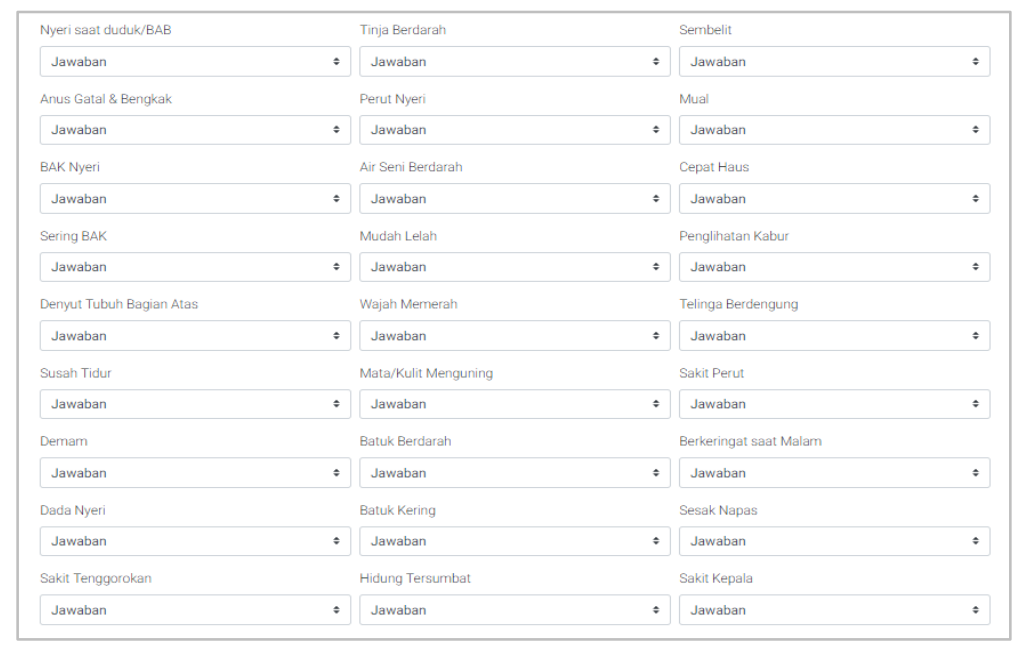

Gambar 3. Halaman Gejala

User dapat melihat kemungkinan penyakit yang diderita beserta nilai kemungkinan dan informasi penanganannya. Nilai kemungkinan user terkena penyakit yang diderita berupa angka persentase yang masing-masing nilai persentase kemungkinan memiliki nilai interpretasi kesimpulan berdasarkan hasil wawancara dengan pakar. Setiap hasil diagnosa penyakit 
diberikan informasi singkat tentang penyakit dan ramuan bawang Dayak kepada user. User dapat melihat informasi penyakit dan cara pengolahan ramuan bawang Dayak penyakit tersebut dengan menekan nama penyakit yang diderita user pada bagian bawah halaman hasil diagnosa. Tampilan Halaman Hasil Diagnosa dapat dilihat pada gambar 4.

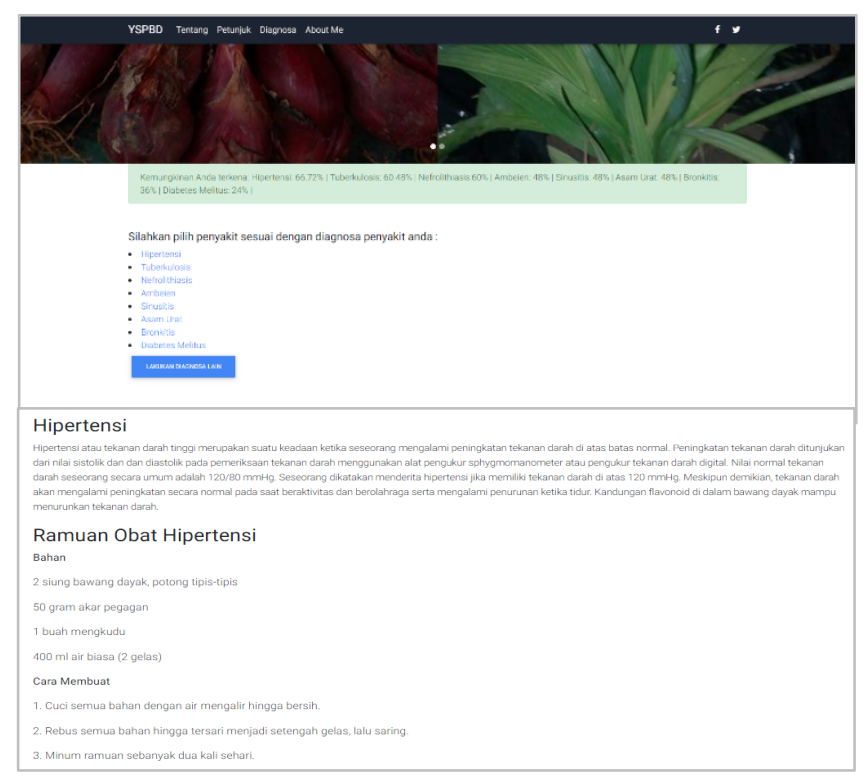

Gambar 4. Halaman Diagnosa

\section{KESIMPULAN}

Sistem pakar ini mampu menyimpan representasi pengetahuan pakar berdasarkan nilai kepastian (Certainty Factor),dengan 10 penyakit yang dapat didiagnosa oleh sistem. Sistem pakar bawang dayak ini dapat digunakan masyarakat dalam diagnosa dini terhadap penyakit yang dapat disembuhkan bawang dayak dan cara membuat ramuannya, sebelum melakukan konsultasi langsung kepada pakar atau dokter.

\section{REFERENSI}

Arwati, N., Wirjatmadi, B., Adriani, M., Meilanani, S., Winarni, D., \& Hartiningsih, S. (2018). The Effect of Dayak Onion Bulb-Stem (Eleutherine Palmifolia (L.,) Merr.) Extract on Blood Glucose Levels of Mouse Suffered Diabetes Mellitus. Health Notions, 2(3), 368372. https://doi.org/10.33846/hn.v2i3.153

Bahtiar, A., \& Dewi, R. (2019). Antiosteoporosis Effects of 70\% Ethanolic Extract Combination of Dayak Onion Bulbs (Eleutherine bulbosa (Mill.) Urb) and Cowpea (Vigna unguiculata (L.) Walp.) on the Hypoestrogen Rats. Pharmacognosy Journal, 11(4).

Brezensky, R., \& Kurniawan, T. B. (2019). PERANCANGAN APLIKASI BIMBINGAN KKL, KP, TA BERBASIS WEB UNTUK MAHASISWA DAN DOSEN STUDIKASUS: PROGRAM STUDI SISTEM INFORMASI. Bina Darma Conference on Computer Science (BDCCS), 1(4), 1013-1021.

Budiman, E., Hairah, U., Haeruddin, Tejawati, A., Darmawan, S., \& Wahyuni, S. (2018). Biodiversity Information System of Medicinal Plants from Tropical Rainforest Borneo Based on Traditional Knowledge Ethnic of Dayak. Advanced Science Letters 24, 8668- 
8673.

Dengen, N., Budiman, E., Widians, J. A., Wati, M., Hairah, U., \& Ugiarto, M. (2018). Biodiversity information system: Tropical rainforest borneo and traditional knowledge ethnic of dayak. Journal of Telecommunication, Electronic and Computer Engineering, 10(1-9).

Gunawan, E. P., \& Wardoyo, R. (2018). An expert system using certainty factor for determining insomnia acupoint. IJCCS (Indonesian Journal of Computing and Cybernetics Systems), 12(2), 119-128.

Harlita, T. D., Oedjijono, \& Asnani, A. (2018). The antibacterial activity of dayak onion (Eleutherine palmifolia (L.) merr) towards pathogenic bacteria. Tropical Life Sciences Research, 29(2), 39-52. https://doi.org/10.21315/tlsr2018.29.2.4

Hasni, Y., Aminah, D., \& Tri, W. (2019). The Effect Of Ethanolic Extract Of Dayak Onion (Eleutherine palmifolia (L) Merr) Tuber On Blood Glucose And Insulin Level Of Strepzotocin-Induced Diabetic Wistar Rat. Asian Journal of Pharmaceutical Research and Development, 7(4), 38-42. http://dx.doi.org/10.22270/ajprd.v7i4.548

Johan, H., Hairah, U., \& Budiman, E. (2017). Ethnobotany database: Exploring diversity medicinal plants of Dayak tribe Borneo. 2017 4th International Conference on Electrical Engineering, Computer Science and Informatics (EECSI), 1-6.

Lesmana, H., \& Parman, D. H. (2019). UTILIZATION OF DAYAK ONION AS HEALTHY SNACKS. International Journal of Nursing and Health Services (IJNHS), 2(4), 397-402.

Setyawan, A. B. (2019). EFEKTIFITAS TEH BAWANG DAYAK UNTUK MENURUNKAN TEKANAN DARAH PADA PASIEN HIPERTENSI. Seminar Ilmiah Nasional Teknologi, Sains, Dan Sosial Humaniora (SINTESA), 2(1).

Widians, J.A., Puspitasari, N., \& Ameilia, U. (2018). Expert System of Black Orchid Cultivation using Certainty Factor Method. Proceedings - 2nd East Indonesia Conference on Computer and Information Technology: Internet of Things for Industry, EIConCIT 2018. https://doi.org/10.1109/EIConCIT.2018.8878534

Widians, J.A., Puspitasari, N., \& Febriansyah, A. (2019). Disease Diagnosis System Using Certainty Factor. ICEEIE 2019 - International Conference on Electrical, Electronics and Information Engineering: Emerging Innovative Technology for Sustainable Future. https://doi.org/10.1109/ICEEIE47180.2019.8981421

Widians, J.A., Puspitasari, N., \& Sari, A. F. A. (2019). The prediction of tourist visiting with average based fuzzy time series method. International Journal of Engineering and Advanced Technology, 8(5). https://doi.org/10.35940/ijeat.E1215.0585C19

Widians, Joan Angelina, \& Budiman, E. (2020). Sistem Pakar Identifikasi Hama Tanaman Buah Naga. Jurnal Rekayasa Teknologi Informasi (JURTI), 4(1), 11-18.

Widians, Joan Angelina, \& Hidayati, I. (2016). Sistem Pendiagnosa Penyakit Asma Pada Anak Dengan Metode Certainty Factor. SEMNASTEKNOMEDIA ONLINE, 4(1), 3-4.

Widians, Joan Angelina, Pakpahan, H. S., Budiman, E., Haviluddin, \& Soleha, M. (2019). Klasifikasi Jenis Bawang Menggunakan Metode K- Nearest Neighbor Berdasarkan Ekstraksi Fitur Bentuk dan Tekstur. Jurti, 3(2).

Widians, Joan Angelina, \& Rizkyani, F. N. (2020). Identifikasi Hama Kelapa Sawit menggunakan Metode Certainty Factor. ILKOM Jurnal Ilmiah, 12(1), 58-63. https://doi.org/10.33096/ilkom.v12i1.526.58-63

Widians, Joan Angelina, \& Wati, M. (2017). Aplikasi Sistem Pakar Tingkat Depresi Certainty Factor. STMIK AMIKOM Yogyakarta, 4-9.

Widians, Joan Angelina, Wati, M., Tejawati, A., \& Budiman, E. (2018). Biodiversity Information System for Management of Medicinal Plants Data Tropical Rainforest Borneo. International Journal of Engineering \& Technology, 7(4.44), 31-36. 